\title{
E-Cigarettes, Vaping, and Youth
}

Lawrence O. Gostin

Georgetown University Law Center, gostin@law.georgetown.edu

Aliza Y. Glasner

Georgetown University Law Center, ayg8@law.georgetown.edu

This paper can be downloaded free of charge from:

https://scholarship.law.georgetown.edu/facpub/1357

http://ssrn.com/abstract=2462247

JAMA (2014)

This open-access article is brought to you by the Georgetown Law Library. Posted with permission of the author. Follow this and additional works at: https://scholarship.law.georgetown.edu/facpub

Part of the Food and Drug Law Commons, Health Law and Policy Commons, Health Policy Commons, Public Health Commons, and the Public Policy Commons 
VIEWPOINT

Lawrence O. Gostin, JD Georgetown University Law Center, O'Neill Institute for National and Global Health Law, Washington, DC.

Aliza Y. Glasner, JD Georgetown University Law Center, O'Neill Institute for National and Global Health Law, Washington, DC.

\section{Corresponding}

Author: Lawrence $\mathrm{O}$.

Gostin, JD,

Georgetown University

Law Center, O'Neill

Institute for National

and Global Health Law,

600 New Jersey Ave

NW, Washington, DC

20001 (gostin@law

.georgetown.edu).

\section{E-Cigarettes, Vaping, and Youth}

The Family Smoking Prevention and Tobacco Control Act of 2009 empowered the US Food and Drug Administration (FDA) to regulate tobacco, the leading preventable cause of death. The agency, however, initially exercised authority only over specific tobacco products: cigarettes, cigarette tobacco, roll-your-own (loose tobacco), and smokeless tobacco. This decision left other forms of tobacco unregulated. Five years later, in April 2014, the FDA sought to close this regulatory gap by issuing proposed rules-referred to as "deeming"-to regulate electronic cigarettes, cigars, pipe tobacco, nicotine gels, waterpipe (hookah) tobacco, and orally ingested dissolvable tobacco products. The proposed rules represent a watershed moment in tobacco control but do not go far enough in regulating e-cigarettes, a product with uncertain benefits and potentially significant harms.

As their usage has increased substantially, e-cigarettes have spurred enormous controversy. ${ }^{1}$ E-cigarettes, which vary in power and potency, typically contain a nicotine-based liquid that is vaporized and

\section{The conundrum is how to regulate e-cigarettes given scientific uncertainty about the nature and extent of harms.}

approval. Further, companies would be permitted to make claims for reduced risk only if the agency confirms the claim based on scientific evidence while also finding a benefit to the health of the public.

Although a vital step forward, the proposed rules leave major issues unanswered, notably those regarding the use of flavored nicotine and marketing practices. By contrast, in February 2014, the European Union issued a Tobacco Products Directive to safeguard youth, including bans on advertising, promoting taste, and nicotine flavorings for e-cigarettes. ${ }^{2}$ Other countries, including Brazil, Lebanon, and Singapore, have banned e-cigarettes entirely.

A lengthy rule-making process has compounded the concerns associated with the proposed rules. Mired in litigation, the FDA has been working since 2011 to extend its deeming authority, and it may be years before the proposed rules are finalized. Even then, the FDA plans to wait 2 years before enforcing warning labels and requiring manufacturers to submit product applications. In the interim, new products will be permitted to enter the market without preapproval, while the popularity of youth "vaping," the colloquial term for e-cigarette use, continues to increase.

\section{Balancing Benefits With Harms}

Preliminary evidence demonstrates the potential of e-cigarettes to reduce harm by weaning smokers from combustible

inhaled. Public health advocates have debated whether e-cigarettes are effective harm reduction tools or offer a pathway to smoking. By delivering nicotine and mimicking oral inhalation, e-cigarettes could reduce dependency on combustible cigarettes and prevent relapse. Alternatively, e-cigarettes could become a gateway to smoking by exposing young people to the world of nicotine and relegitimizing tobacco use in society. Probably both scenarios are true: e-cigarettes can help older, entrenched smokers to quit smoking, whereas younger nonsmokers could transition from electronic to combustible cigarettes once they are addicted to nicotine.

\section{FDA Proposed Rule}

As proposed, the FDA rules would set a federal minimum age of 18 years to use e-cigarettes, require identification to purchase them (currently, just more than half of states impose age restrictions), prohibit most sales in vending machines, mandate warning labels on packaging, and prohibit manufacturers from providing free samples.

Companies would be required to register e-cigarettes with the FDA, submit safety data, and disclose product ingredients. FDA inspectors would monitor compliance. Companies would be able to introduce new products to the market only after FDA review and tobacco, but the benefits appear minimal. At the same time, evidence of harm is emerging. More powerful e-cigarettes, commonly known as tank systems, heat nicotine liquid hot enough to produce cancer-causing carcinogens, such as formaldehyde and acetaldehyde, in their vapor. ${ }^{3}$ Further, in a study of human bronchial cells that contained some mutations found in smokers at risk of lung cancer, scientists found a pattern of gene expression in cells grown in a medium exposed to ecigarette vapor that was similar to the pattern found in cells grown in a medium exposed to combustible tobacco smoke. ${ }^{4}$ In addition, the virulence of drugresistant bacteria can be increased by e-cigarette vapors and affect the ability of cells to destroy bacteria. ${ }^{5}$

The Centers for Disease Control and Prevention reported an increase in calls to poison control centers after unintentional exposure of children to e-liquid, including oral ingestion, eye contact, and inhalation exposure. ${ }^{6}$ Public reports commonly associated with e-cigarettes include trouble breathing, headache, cough, dizziness, sore throat, nose bleeds, chest pain, heart palpitations, ${ }^{7}$ and allergic reactions such as itchiness and lip swelling. The conundrum is how to regulate e-cigarettes given scientific uncertainty about the nature and extent of harms. 
A New Youth Culture of Vaping

The increasing popularity of vaping has been associated with a surge in nicotine use among adolescents. It took decades of social mobilization and political action to overcome the perception of smoking as "cool," even after the evidence became clear that smoking is deadly. That intensive campaign-supported by smoke-free laws, advertising bans, and package warnings-could easily be reversed by the popularity of vaping. Even though today's youth grew up inculcated with negative social stigma around the use of combustible cigarettes, vaping products are often marketed as highly palatable and accessible alternatives. In recent years, tobacco companies such as Altria as well as niche manufacturers like NJoy have aggressively entered this market by reinventing brand appeal and normalizing vaping.

With the decline in recent years in the prevalence of young tobacco smokers-the most profitable long-term consumers-it is no surprise that youth are a key demographic of the vaping campaign. Colorful advertisements touting flavors such as bubble gum or with celebrity actors conjure images of Joe Camel and the Marlboro Man. The industry skirts accusations of deliberately catering to youthful consumers by asserting that e-cigarettes are a safer alternative to combustible cigarettes or positioning e-cigarettes as nicotine replacement therapies. ${ }^{8}$

The Centers for Disease Control and Prevention reported that between 2011 and 2012, the proportion of high school students who had tried e-cigarettes doubled from $4.7 \%$ to $10 \% .{ }^{9}$ Although alarming, this figure significantly underestimates the proliferation of nicotine intake by vaping among adolescents. The study directly addressed e-cigarettes but left out a related class of devices that also create a nicotine vapor: e-hookahs, hookah pens, and vape pipes.

The failure of adolescents to equate vaping products generally with e-cigarettes underscores how successful the tobacco industry has been in reinventing a popular "smoking" trend. The FDA em- phasizes the power of social norms in influencing behavior. For instance, the agency points to the "value of strict access restrictions" to "symbolize and reinforce an emerging social norm that disapproves of tobacco use." ${ }^{10}$ However, by failing to restrict advertising and flavored nicotine for e-cigarettes, the agency could be undermining its own conclusions. Child-friendly flavors and slick promotions might encourage young people to experiment with vaping and potentially increase smoking rates among youth. This outcome appears inconsistent with the FDA emphasis on creating social norms to limit the proliferation of tobacco.

\section{Important Next Steps}

The oral satisfaction of e-cigarettes, together with their ability to deliver nicotine without combusting tobacco, poses a double-edged sword for public health. Although it will be easier to replace one highly dangerous addiction (cigarettes) with a seemingly less dangerous alternative (e-cigarettes), the same dynamics may recruit many young people, addicting them to nicotine, with some transitioning to combustible tobacco. There is also a major risk that e-cigarettes will revive the popular smoking culture that has taken decades to dismantle.

The FDA deeming proposal offers the welcome promise of a regulatory structure to ensure that e-cigarettes and other vaping products are safe and effective. However, the agency should move boldly and rapidly to prevent companies from exploiting youth. By bolstering the proposed rules to limit advertising and prohibit flavored nicotine, the agency could prevent proliferation of e-cigarette use among adolescents, while not undermining its regulatory goal of reducing harm. Before the comment period on the proposed rules closes in July, the public health community should speak with a clear voice to urge meaningful and effective regulation to protect US youth against the reinvention of Big Tobacco.

\section{ARTICLE INFORMATION}

Published Online: June 30, 2014

doi:10.1001/jama.2014.7883.

Conflict of Interest Disclosures: The authors have completed and submitted the ICMJE Form for Disclosure of Potential Conflicts of Interest and none were reported.

\section{REFERENCES}

1. Abrams DB. Promise and peril of e-cigarettes: can disruptive technology make cigarettes obsolete? JAMA. 2014;311(2):135-136.

2. European Commission. Health-EU Newsletter: New EU Tobacco Control Measures. February 27, 2014;(24). European Commission website. http://ec .europa.eu/health/newsletter/124/newsletter_en .htm. Accessed May 27, 2014

3. Kosmider L, Sobczak A, Fik M, et al. Carbonyl compounds in electronic cigarette vapors-effects of nicotine solvent and battery output voltage [published online May 15, 2014]. Nicotine Tob Res. doi:10.1093/ntr/ntu078.

4. Park SJ, Walser TC, Perdomo C, et al. The effect of e-cigarette exposure on airway epithelial cell gene expression and transformation [Abstract B16]. Clin Cancer Res. 2014;20. Cited by Cressey D.
E-cigarettes affect cells. Nature. 2014;508(7495): 159. http://www.nature.com/news/e-cigarettes -affect-cells-1.15015. Accessed June 3, 2014

5. Crotty Alexander LE, Enany S, Hwang $\mathrm{H}$, Sladewski K, Nizet V. Electronic cigarette vapor (ECV) exposure decreases Staphylococcus aureus susceptibility to macrophage and neutrophil killing. Presented at: 2014 American Thoracic Society meeting; May 16-21, 2014; San Diego, California. Abstract 57341

6. Centers for Disease Control and Prevention (CDC). New CDC Study Finds Dramatic Increase in E-Cigarette-Related Calls to Poison Centers. CDC website. http://www.cdc.gov/media/releases/2014 /p0403-e-cigarette-poison.html. April 3,

2014.Accessed May 27, 2014.

7. US Food and Drug Administration (FDA). CTP FOIA Electronic Reading Room: E-cigarette adverse events 6/22/2009 to 3/12/2014. http: //www.fda.gov/AboutFDA/CentersOffices /OfficeofMedicalProductsandTobacco /AbouttheCenterforTobaccoProducts/ucm221165 .htm. Accessed June 3, 2014.

8. US House of Representatives Democrats Committee on Energy and Commerce. Gateway to Addiction? A Survey of Popular Electronic Cigarette
Manufacturers and Targeted Marketing to Youth. Democrats Committee on Energy and Commerce website. http://democrats.energycommerce .house.gov/sites/default/files/documents/Report -E-Cigarettes-Youth-Marketing-Gateway-To -Addiction-2014-4-14.pdf. April 14, 2014. Accessed June 3, 2014

9. Centers for Disease Control and Prevention (CDC). Notes from the field: electronic cigarette use among middle and high school students-United States, 2011-2012. MMWR Morb Mortal Wkly Rep. 2013;62(35):729-730http://www.cdc.gov/mmwr /preview/mmwrhtml/mm6235a6.htm. Accessed May 27, 2014.

10. US Food and Drug Administration. (FDA). Deeming Tobacco Products to Be Subject to the Food, Drug, and Cosmetic Act, as Amended by the Family Smoking Prevention and Tobacco Control Act; Regulations Restricting the Sale and Distribution of Tobacco Products and Required Warning Statements for Tobacco Product Packages and Advertisements. FDA website. http://www.fda.gov/downloads/AboutFDA /ReportsManualsForms/Reports /EconomicAnalyses/UCM394933.pdf. Published April 2014. Accessed May 27, 2014. 